\title{
Liberalizam i Katolička crkva - dijaloška vizija Željka Mardešića
}

Marko Medved*

markofelix@yahoo.com

Nataša Varga Padovan**

natashavarga@yahoo.com
UDK: 316.2 Mardešić, Ž. 329.12:282]:262.5 Vat.2

Izvorni znanstveni rad / Original scientific paper Primljeno: 3. veljače 2017. Prihvaćeno: 10. travnja 2017.

Od hrvatskih katolika Željko Mardešić bio je jedan od naglasnijih zagovaratelja susreta kršćanstva i liberalizma, odnosno dijaloga vjernika $i$ modernog svijeta na principima koncilskog nauka. Kao kompetentan poznavatelj hrvatskih $i$ svjetskih religioznih kretanja, nikada nije ostao samo puki akademski intelektualac, već je bio autentičan kršćanin. Drugi vatikanski koncil snažno je obilježio njegov znanstveni $i$ vjernički angažman. Dok je u 19. st. prevladavala suprotstavljenost izmedu dvaju pogleda na svijet, znanstvenog $i$ vjerskog, kao $i$ odnosa prema društvenom poretku, Željko Mardešić tvrdi da je dijalog kršćanstva $i$ moderniteta potreban $i$ ostvariv na temelju Drugog vatikankog sabora. Ukazujući na kršćanske principe moderniteta, odbacujući politički katolicizam i vrednujući demokraciju, Mardešić povlači neprekinutu crtu između prvog kršćanstva i moderniteta.

Ključne riječi: Željko Mardešić, liberalizam, katolicizam, integrizam, Drugi vatikanski sabor, sekularizacija.

\footnotetext{
* Doc. dr. sc. Marko Medved, Katedra crkvene povijesti Katoličkoga bogoslovnog fakulteta Sveučilišta u Zagrebu - Teologija u Rijeci; Omladinska 14, HR-51000 Rijeka.

**Nataša Varga Padovan, mag. theol.; Mihačeva Draga 21, HR-51000 Rijeka.
} 


\section{Uvod}

Pitanje odnosa Katoličke crkve i liberalizma u 19. st., šire kršćanstva i svijeta nakon prosvjetiteljstva, od posebne je važnosti ne samo za crkvenu povijest, već i za cjelokupnu teologiju. Hrvatski historičari, uključujući i crkvene povjesničare, već su se bavili odnosom Katoličke crkve u nas i liberalizma. Pristupi, ocjene i zaključci različiti su. ${ }^{1}$ Katkad se objavljuju radovi koji ne uzimaju u obzir zaključke suvremene crkvene historiografije. ${ }^{2}$

Jedan od najhrabrijih i najtemeljitijih hrvatskih katoličkih autora u tim pitanjima bio je sociolog religije Željko Mardešić. Kao kompetentan poznavatelj hrvatskih i svjetskih religioznih kretanja, nikada nije ostao samo puki kabinetski intelektualac, već je bio autentičan i angažiran kršćanin. Nije bio povjesničar, što znači da prvenstveno nije bio usmjeren korištenju arhivskih vrela, već dosezima sociologije religije i sociologije povijesti. Unatoč tome, ovo je povijesno razdoblje analizirao polazeći od nauka Drugog vatikanskog koncila. Naime, Drugi vatikanski koncil snažno je obilježio Mardešićev znanstveni i vjernički angažman. ${ }^{3}$

\footnotetext{
${ }^{1}$ Mirko Juraj MATAUŠIĆ, Odnos Katoličke crkve prema najnovijim idejnim strujanjima u hrvatskim zemljama 1848.-1900., Bogoslovska smotra, 55 (1985) 1-2, 196-215; Slavko SLIŠKOVIĆ, Crkva i nacionalni identitet, u: Valentina Blaženka MANDARIĆ - Ružica RAZUM (ur.), Identitet kao odgojno-obrazovna vrjednota, Zbornik radova s tribina Zajednički vidici, Zagreb, Glas Koncila, 2011, 130-136; Franjo Emanuel HOŠKO, Liberalni katolicizam kao sastojnica ideologije ilirizma, Croatica Christiana periodica, 15 (1991) 28, 43-54; Jure KRIŠTO, Prešućena povijest. Katolička crkva u hrvatskoj politici 1850.-1918., Zagreb, Hrvatska sveučilišna naklada, 1994; Mario STRECHA, Katoličko hrvatstvo. Počeci političkog katolicizma u banskoj Hrvatskoj (1897-1904), Zagreb, Barbat, 1997.

2 Primjer takvih pristupa je Stephen Nikola BARTULICA, Liberalizam i religija, Nova prisutnost, 14 (2016) 1, 16-33. Bez obzira što se više bavi političkom filozofijom, takva analiza crkvenom povjesničaru čini se manjkavom, stoga neprihvatljivom, jer ne vodi računa o odnosima Crkve i države u Europi u 19. stoljeću, kao i o promjenama crkvenog nauka prema modernitetu i liberalnom poretku, npr. u pitanju vjerske slobode (deklaracija Dignitatis humanae). Naime, crkveno je učiteljstvo u 19. st., pod dominacijom intranzigentne struje, odbacivalo ono što danas nakon Koncila prihvaća (tipičan primjer Syllabus iz 1864.). U prosudbi iskustva liberalizma i religije crkveni će povjesničar voditi računa i o odnosima europskog (i hrvatskog) katoličanstva s liberalizmom u prošlosti, o tome da su liberalna strujanja u 19. st. bila povezana s nacionalnim pitanjem, da su u tim pokretima aktivno sudjelovali i katolici, da je bilo i i liberalnih katolika, među kojima i naš J. J. Strossmayer, i onih koje je Katolička crkva u međuvremenu beatificirala poput Antonija Rosminija, a koje tada Rimska kurija nije smatrala pravovjernim. Ne mogu se davati sudovi o odnosu Crkve i liberalizma ne vodeći računa o zaključcima suvremene crkvene historiografije: Hubert JEDIN (ur.), Velika povijest Crkve, sv. VI/1, Zagreb, Kršćanska sadašnjost, 1987; G. MARTINA, Storia della Chiesa, sv. 3, Letà del liberalismo, Brescia, Morcelliana, 1995, 253-274.

3 Željko Mardešić (rođen u Milni na otoku Braču 1933. - umro u Splitu 2006.) po formalnoj vokaciji bio je pravnik, ali je glavninu svojih intelektualnih potencijala ostvario na području sociologije religije postigavši ugled vodećeg stručnjaka na tome području u nas. O njemu je časopis Nova prisutnost već mnogo puta pisao.
} 


\section{Liberalizam}

Liberalizam možemo definirati kao pokret koji u misaonom i političkom pogledu teži priznavanju autonomije pojedinca i ograničenju uloge države, temeljeći se na razlikama između privatne i javne sfere. Nastaje u Europi nakon renesanse i reformacije, a na temelju više čimbenika: borbe za vjersku toleranciju, suprotstavljenosti između apsolutizma dinastije Stuart i engleskog plemstva koje je od krune uspjelo zadobiti sudske i političke garancije, trodiobe i ravnoteže vlasti po Montesquieuovoj teoriji, Rousseauovog ugovornog viđenja društvene stvarnosti. Na ekonomskom planu to je gospodarski individualizam po kojemu društvo ima najveću korist ako je osigurano posve slobodno natjecanje i konkurencija bez ikakvih mjera ograničenja državne intervencije. Američka deklaracija iz 1776. i Francuska revolucija 1789. nastaju u tome kontekstu, pozivajući se na principe slobode savjesti, slobode misli, izražavanja i udruživanja, jednakosti spram zakona i prava na sudjelovanje u stvaranju zakona i prava vlasništva.

\section{Mardešićevo viđenje odnosa Crkve i liberalizma u prošlosti}

Mardešić objašnjava da za razliku od engleskih začetnika liberalizma koji su bili nadahnuti deizmom, francuski liberali iskazuju otvoreno neprijateljstvo prema Crkvi, promatrajući je politički i ideološki. Tako na scenu dolazi sukob Crkve i države. No Mardešić pojašnjava kako ipak nije riječ o sukobu vjere i nevjere, već o suprotstavljanju države i Crkve. Sukob svjetovne državne vlasti i svjetovne moći Crkve završava najprije separacijom jedne od druge, a potom protjerivanjem Crkve na sam rub društva putem procesa sekularizacije. ${ }^{4}$

U kristijaniziranoj Europi srednjega vijeka uopće se nije postavljala mogućnost protivljenja kršćanskome društvu, a dolaskom prosvjetiteljstva i liberalizma otvorio se put za alternativni, često otvoreno neprijateljski odnos prema Crkvi. ${ }^{5}$ Nakon Francuske revolucije Crkva je brojila ubijene svećenike i oskvrnute oltare, oduzeta zemljišta i srušene samostane, ali je, tvrdi Mardešić, previdjela tražiti uzroke tome golemu neredu u grijehu struktura, nalazeći ih radije $u$ ideologiji protivnika. Ističe da Rim ni izdaleka nije bio svjestan dometa Francuske građanske revolucije. U igri je, dakle, bio odnos Crkve i države, najprije one kršćanske starog poretka, a onda one laičke iz modernog doba. Napoleon i konkordat iz 1802. godine, potom restauracija nakon Bečkog kongresa 1815., novi su poredak pokušali osporiti, ali bez trajnijeg uspjeha. Naime, kroz cijelo 19. i

\footnotetext{
${ }^{4}$ Jakov JUKIĆ, Kršćanstvo i liberalizam, Društvena istraživanja, 4 (1995) 6, 895.

${ }^{5}$ Isto, 892.
} 
do polovine 20. stoljeća, tvrdi Mardešić, crkveno učiteljstvo osuđuje vladanje pojedinih liberalnih država. ${ }^{6}$

Središnji pontifikat 19. stoljeća bio je onaj Pija IX. (1846.-1878.). On će, uz encikliku Quanta cura, objaviti i Syllabus seu collectio errorum modernorum 1864. godine kojim je osudio ono što je smatrao zabludama modernoga doba, a u posljednjoj točki, koja je inače najviše tumačena, izrijekom je odbacio napredak, liberalizam i modernu civilizaciju. Mardešić vidi nastavak slične prakse u pontifikatu Pija X. i njegovoj enciklici Pascendi iz 1907. koja se bori protiv modernizma. Upravo je u toj osudi modernizma, shvaćenoj kao omnium haereseon collectum, smatra Mardešić, sadržano izopćenje liberalizma u njegovu najširem i najopćenitijem značenju, što će neprekinuto trajati sve do Drugog vatikanskog koncila. ${ }^{7}$ Na drugome će mjestu Pija IX. i Pija X. Mardešić nazvati »obnoviteljima protureformacijski shvaćenog katolicizma«. ${ }^{8}$

Tako dolazi do jaza i suprotstavljanja između Crkve i suvremenoga svijeta, a mogućnost dijaloga posve je iščezla. U krilu Crkve rađa se intranzigentni katolicizam, u čijem se opisu Mardešić uvelike služi prosudbama Émilea Poulata, jednog od poznatijih francuskih povjesničara u pitanjima suvremene crkvene povijesti, posebice modernizma. ${ }^{9}$

\subsection{Integrizam se opire modernitetu}

Analizirajući povijest 19. st. Mardešić piše da je prvotni odgovor Crkve na modernitet bio integrizam (ili integralizam) čime su odbačene one sastavnice novog poretka koje danas smatramo kršćanskima, poput ljudskih prava. Modernitet se percipirao kao veliko zlo pred kojim se Crkva povukla u idealiziranje prošlosti, u nostalgiju za ancien régime koji je intranzigentnim katolicima pružao sigurnost. Bio je to, kako ga Mardešić naziva, neizvediv pothvat povratka društva u predmodernitet, posebice u srednjevjekovlje i protureformaciju. U odmaku i oporbi spram moderniteta unutar katoliciteta Mardešić prepoznaje osobito dva obilježja: integrizam i fundamentalizam. Na tragu prosudbe prije spomenutog francuskog autora E. Poulata, taj integrizam Mardešić opisuje kao idealiziranje prošlosti i protivljenje svakoj promjeni. Mardešić vuče paralelu između integrizma 19. i početka 20. stoljeća s fundamentalizmom postkoncilskog

\footnotetext{
${ }_{6}$ Željko MARDEŠIĆ, Crkva, liberalizam i modernitet, u: Hans-Georg FLECK (prir.), Liberalizam i katolicizam u Hrvatskoj, sv. II, Zagreb, Zaklada Friedrich Neumann, 1999, 447-448.

7 Jukić, Kršćanstvo i liberalizam..., 892.

8 Željko MARDEŠIĆ, Hrvatski katolički pokret i liberalizam, u: Zlatko MATIJEVIĆ (ur.), Hrvatski katolički pokret, Zbornik radova s Međunarodnoga znanstvenog skupa održanog u Zagrebu i Krku od 29. do 31. ožujka 2001, Zagreb, Kršćanska sadašnjost, 2002, 265.

${ }^{9}$ Francuski povjesničar i sociolog Émile Poulat (1920.-2014.), proučavao je modenu crkvenu povijest. Objavio je zapažena djela o modernistčkoj krizi, odnosu Crkve spram masonerije, kao i o pitanju laiciteta.
} 
vremena. ${ }^{10}$ Želju za povratkom u konstantinovsko razdoblje Mardešić uočava i nakom Drugog vatikanskog koncila kod onih koji su pretkoncilski usmjereni. ${ }^{11}$

\subsection{Mardešićeve kritike Hrvatskom katoličkom pokretu}

Kada se promatra odnos Crkve i liberalizma u nas od posebnog je značenja Hrvatski katolički pokret s početka 20. stoljeća. Početke i razvoj katoličkog pokreta u nas Mardešić posebno povezuje s pontifikatima Lava XIII. (1878.-1903.)

$\overline{10} \gg$ Prvi odgovor Crkve na modernitet poznat je pod imenom integrizam. Ona je njime doslovce odbacila sve vrijednosti novovjekog svijeta, pa i one koje danas držimo kršćanskima kao što su obrana ljudskih prava, religiozna sloboda, odvojenost Crkve od države i demokracija. Modernitet je time bio potpuno izjednačen s velikim Zlom iz starih dualizama i neprizivno osuđen na poraz od velikoga Dobra. No kako je ipak bila riječ o sukobu svjetovnih moći i političkog utjecaja, Crkva se pred naletom mladog moderniteta nije upustila u izravan obračun i pokušaj njegova uništenja, nego se radije povukla u prošlost, tražeći načina da se obnove navodno dobra i stara vremena srednjevjekovlja i protureformacije. Otud dvije oznake integrističkog dualizma: idealiziranje prošlosti i slijedom toga, protivljenje svakoj promjeni i napretku općenito. U tom se smislu može reći da je integrizam bio nekom vrsti nostalgije za prednostima katolika iz ancien régimea. Zato bilo kakvu predodžbu o budućnosti kršćanstva integrizam uopće nije ni imao, a niti se trudio o tome razmišljati. Sva je njegova novost bila u prošlosti. Crkveno se nijekanje moderniteta sastojalo dakle u neizvedivom pothvatu povratka društva u predmodernitet. Po sebi se razumije da pristupi u pogledu određenja integrizma - neki ga zovu i integralizmom - nisu u potpunosti usuglašeni. U tom okviru nije dvojbeno kako žestoki prijepori i osude teološkog modernizma od strane pape Pija X. tvore tek okosnicu integrizma, ali ga nikako ne iscrpljuju. Još manje se on može svesti samo na egzegetsko pitanje, iako mu je svakako u korijenu. Riječ je prije o skupu zajedničkih gledišta najvećeg dijela pretkoncilske teologije koja ide vremenski od Tridentskog koncila pa do pape Pija XII. [...] Drugi odgovor dolazi stoljeće poslije pod imenom katoličkog fundamentalizma. Dosad smo poznavali islamski i protestantski fundamentalizam, a danas se u postkoncilskom razdoblju pojavljuje njima sličan katolički. Možda će to neke iznenaditi, iako se u naše doba u teologiji posve otvoreno i bez skrivanja piše i raspravlja o katoličkom fundamentalizmu. Između pretkoncilskog integrizma i postkoncilskog fundamentalizma postoje zacijelo značajne razlike, ali isto tako i stanovite istovjetnosti koje trebamo naznačiti. Jedni i drugi jednako otklanjaju i osuđuju modernitet, ali su im putevi izlaska iz te povijesne prijetnje katolicizmu oprečni. Dok je integrizam nijekao modernitet bijegom u prošlost, fundamentalizam će to činiti pokušajem pobjede nad modernitetom u sadašnjosti, dajući tako cijelom sukobu posebnu isključivost i naglašenu dramatičnost po uzoru na stare religijske dualizme. Jer za pobjedu se traži mnogo više nego za bijeg, što ima onda za posljedicu povećanu bojovnost, spremnost, fanatizam, ideologičnost, netrpeljivost, pa ponegdje i mržnju. Cilj - pobjeda nad modernitetom - postaje važnijim od sredstva kojima se on postiže. Zato se uostalom fundamentalizam toliko i usredotočio na uništenje modernog svijeta, a ne na izgradnju novog kršćanskog svijeta« (Željko MARDEŠIĆ, Rascjep u svetom, Zagreb, Kršćanska sadašnjost, 2007, 860-862).

${ }_{11}$ Ima se dojam kako su neki od katolika postali najvećim neprijateljima slobode, premda je ona temelj na kojem počiva sva njihova vjera. Još više, uvriježilo se shvaćanje da je sloboda prije prilika za zloupotrebu nego šansa za rast u čovječnosti i kršćanskoj dobroti. Iza svake veće novosti ili hrabrijeg iskoraka vidi se odmah grješna opasnost, a ne pouzdanje u mladost i njezine plemenite snove. To se nepovjerenje u čovjeka pretvorilo u nepovjerenje u Boga, pa pretkoncilska misao biva prisiljena pristati uz ezoteričnu zamisao o pretpostavljenoj uroti cijeloga svijeta protiv Crkve, što je samo nastavak osuda iz dana Syllabusa. [...] Umjesto da uzljube taj svijet i pokušaju ga spasiti, pretkoncilski nostalgičari bacaju na njega neopozivu anatemu, uzaludno se nadajući povratku u konstantinovsku prošlost (Mardešić, Rascjep u svetom..., 132-133). 
i Pija X. (1903.-1914.). Dok je prvi, nakon dugog pontifikata Pija IX., značio stanovito otvaranje, Pio X. opet je zauzeo nepovoljan stav prema modernitetu.

Mardešić naglašava da su se stavovi hrvatskog klera s početka 20. st. uvelike razlikovali od onih koji su među svećenstvom u nas dominirali koncem 19. stoljeća, kada je dobar dio hrvatskih svećenika u politici i kulturi bio pomirljiv prema liberalnim idejama, pri čemu je prednjačio biskup Josip Juraj Strossmayer. Mardešić objašnjava da se Strossmayer nastojao prilagoditi modernitetu, a ne posve odbaciti ideje Francuske revolucije. ${ }^{12}$ Naklonost dijela hrvatskog svećenstva prema slobodarskim usmjerenjima omogućilo im je da budu nazočni u gotovo svim onodobnim političkim strankama, čime upravo otkrivaju vlastiti liberalni odabir, tvrdi Mardešić. Smatra da su oni zastupali neke od sržnih vrednota toga poretka, barem u politici: narodni suverenitet, opću jednakost pred zakonom, pravo glasa za sve građane i slobodu tiska, te da su baština stanovitog liberalnijeg katolicizma u hrvatskom društvu i učiteljstvo pape Lava XIII., koji je odbacio prethodni kruti integrizam, zaslužni za to da su u nas Crkva i vjernici u 20. stoljeće ušli s manje opterećenosti i više opuštenosti u odnosu na svoju buduću duhovnu i zemaljsku zrelost. ${ }^{13}$ To se, piše Mardešić, u mnogočemu odrazilo na sve uvodne i zaključne tekstove Prvog hrvatskog katoličkog kongresa koji je održan u Zagrebu od 3. do 5. rujna 1900. godine, čije je zaključke pokušao temeljito hermeneutički iščitati. ${ }^{14}$ Dakle, početak HKP-a Mardešić povezuje s pontifikatom Lava XIII., a u hrvatskom kontekstu sa stanovitom liberalnom baštinom vlastitom hrvatskom kleru 19. st. ${ }^{15}$

\subsection{Mardešićeva kritika lista Hrvatska straža}

Godine 1903. umire papa Lav XIII., a izabran je znatno konzervativniji Pio X. Iste godine Anton Mahnić utemeljuje list Hrvatska straža koji će postati gla-

${ }^{12} \mathrm{O}$ tome da se među hrvatskim katolicima još uvijek zazire i prešućuje liberalni katolicizam u Strossmayera i dobrog dijela klera 19. st., Mardešić piše: »O tome se nažalost danas malo zna, a još manje želi doznati« (Mardešić, Hrvatski katolički pokret i liberalizam..., 254).

${ }^{13} »$ Lav XIII. [je] pomirljivi[ji] i snošljivi[ji] prema modernom svijetu od nepovratnih ideoloških osuda Syllabusa prethodnog pape Pija IX. Najkraće rečeno, spletom okolnosti i željom Lava XIII. da pokuša nešto učiniti modernom svijetu, a ne samo ga osuđivati, stvoreni su uvjeti za jedno smirenije i manje opterećeno gledanje na liberalizam « (Mardešić, Hrvatski katolički pokret i liberalizam..., str. 256).

${ }^{14}$ Povjesničar Mario Strecha, kao i Željko Mardešić, zauzima kritički stav prema ideologizaciji katoličanstva, ali Strecha znatno kritičkije nastupa prema Kongresu iz 1900. smatrajući ga korakom u smjeru oživotvorenja političkog katolicizma (usp. Mario STRECHA, Prvi hrvatski katolički kongres - korak naprijed u afirmaciji političkog katolicizma u Banskoj Hrvatskoj, u: Mardešić, Hrvatski katolički pokret i liberalizam..., 171-183). Vidjet ćemo u nastavku da je i Željko Mardešić vrlo kritičan prema političkom katolicizmu, ne samo u prošlosti nego i u sadašnjosti katolika u Hrvatskoj, ali ga u zaključcima navedenog skupa iz 1900. godine još ne uočava.

${ }^{15}$ Mardešić, Hrvatski katolički pokret i liberalizam..., 256-259; Mardešić, Rascjep u svetome..., 816-825. 
som njegovog idejnog i djelatnog usmjerenja radi obrane i obnove prisutnosti katoličkih načela u javnom životu hrvatskog naroda. On je tražio zahtjevnija i tvrđa rješenja u borbi s liberalnom ideologijom, a Mardešić to novo razdoblje naziva vremenom »nepomirljive osude liberalizma«. On ocjenjuje da su Mahnićeve ideje bile mnogo bliže Piju IX. i njegovu Syllabusu, negoli stavovima pape Lava XIII. ${ }^{16}$ Mardešić tvrdi da je Mahnić bio uvjeren da katolici u hrvatskom društvu nisu dostatno uočili opasnost djelovanja prosvjetiteljskih ideja u kulturi, umjetnosti i filozofiji, pa ih je pozivao na nepomirljivu borbu. Nije čudo, razmišlja Mardešić, što Mahnićeva Hrvatska straža za podnaslov uzima sintagmu: Antemurale Christianitatis. U tekstovima toga lista Mardešić vidi veličanje srednjovjekovnih ideala društva u kojemu je vladao sklad između svjetovne vlasti i Crkve, za razliku od modernog razdoblja u kojemu je zavladalo takvo poimanje slobode koje se shvaćalo kao ozračje lažne slobode. ${ }^{17}$

Moglo bi se reći da se glavnina Mardešićevih kritika prema Antunu Mahniću odnosi na ideologiziranje katoličanstva. Naime, Mardešić smatra da je krčki biskup pokušao katolički svjetonazor staviti u prvi plan cijelog hrvatskog društva, a sve drugo njemu podrediti, što je značilo ideologizirati katolicizam..$^{18}$ Bio je naviješten rat liberalizmu i drugim modernim idejama do njihova potpuna iskorijenjenja, pri čemu nije pošteđeno ni nacionalno pitanje. ${ }^{19}$

U središtu prijepora nalazilo se, tvrdi Mardešić, suprotno shvaćanje slobode. Dok je liberalizam slobodu određivao kao središnju čovjekovu vrijednost, dotle je pretkoncilski katolicizam o njoj govorio s velikim zazorom, držeći da je sloboda bitno ograničena razumom, zlim ishodom i vjerskim učenjem. Između istine i slobode, dakle, nema i ne može nikad biti nikakva sporazuma i po-

\footnotetext{
${ }^{16}$ Mardešić, Hrvatski katolički pokret i liberalizam..., 261.

${ }^{17}$ Isto, 261 i 263. Kod Antemurale Christianitatis riječ je dakle o parafrazi sintagme iz vremena obrane od otomanske vlasti koju intranzigentni kaolicizam u suvremenom razdoblju primjenjuje protiv moderniteta (isto, 268-269).

18 »U osobi mladog krčkog biskupa Hrvatska je dobila jamačno svojeg prvog i najizrazitijeg ideologa katolicizma. Ni prije, a niti poslije neće ga u tome baš nitko nadmašiti. Zato s Mahnićem nastupa u hrvatskom katolicizmu burno razdoblje isključivo ideološkog određenja vjere i crkvenog djelovanja. Sve je podvrgnuto idejnom osvajanju i posvajanju svjetovnog društva u smislu katoličkog svjetonazora, pa ostalo dolazi poslije i uvijek u ovisnosti o tom cilju. Uvjeren da katolici u hrvatskom društvu nedostatno uočavaju svu opasnost djelovanja prosvjetiteljskih ideja u kulturi, umjetnosti i filozofiji, A. Mahnić će ih sve pozvati na nepomirljivi ideološki rat do istrebljenja neprijatelja. Otud dojam da je u pojedinim trenucima bio gotovo opsjednut prijetnjama liberalizma« (Mardešić, Hrvatski katolički pokret i liberalizam..., 261).

${ }^{19}$ Slično tvrdi Slavko Slišković: »Na kraju 19. stoljeća mlado svećenstvo stupa u aktivnu politiku s ideologijom tradicionalnog shvaćanja društvene uloge katoličanstva i Katoličke crkve, odnosno učenja o uskoj povezanosti duhovnog i svjetovnog te nedopustivosti njihova potpunog odvajanja. Glavni cilj postalo im je sprječavanje stvaranja pravnog okvira koji bi ubrzao proces sekularizacije. Ujedno su se trudili afirmirati katoličke vrijednosti kao načela na kojima se treba temeljiti ukupna hrvatska društvena zbilja. Tako nastaje fenomen političkog katolicizma ili 'katoličkog' hrvatstva. [...] Katoličko hrvatstvo pak isključivalo je sve drugo. Nije htjelo biti samo duhovni temelj na kojemu bi se gradila hrvatska nacija, nego samo njezino središte, čime bi došlo do potpune identifikacije katolicizma i hrvatstva. U tome se ide tako daleko da se katolicizam naziva svetom vjerom hrvatskom « (Slišković, Crkva i nacionalni identitet..., 134-135).
} 
mirbe, jer su to dvije do krajnosti suprostavljene stvarnosti. U konačnici istina je ta koja određuje što je sloboda, a ne obratno. S tim u vezi, tvrdi Mardešić, Hrvatska straža otklanjala je svaku mogućnost uvođenja slobode tiska, govora i škole, posebice u odnosu na katoličke zasade, koje se ne treba propitkivati već spasonosno prihvaćati. Sloboda uvijek dolazi poslije istine i mora biti u punom skladu s njom. Obrnuta logika ni pod kojim uvjetom ne vrijedi. Na udaru se našla osobito tolerancija kao jedan od temeljnih stupova liberalizma. Tko, naime, zastupa građansku snošljivost, jednako vjersku i svaku drugu, stavlja pod istu razinu istinu i laž, ispravnu spoznaju i zabludu. Ista će mjerila biti korištena i za politički život i javno djelovanje koje nije dopušteno ocjenjivati izvan moralnih i vjerskih načela. Za Hrvatsku stražu gori od zagovornika prosvetiteljstva i liberala, bili su oni katolici koji teže pomirenju s takvim idejama. Za tada mladog krčkog biskupa, između Katoličke crkve i modernog društva nema, i nikad ne može biti, sporazumijevanja i usklađenja, jer su to dva posve nesvediva i nepomirljiva svijeta. Glavni cilj Hrvatskoj straži bio je nestanak liberalizma u onodobnom hrvatskom društvu. ${ }^{20}$

Povijesno gledajući, obračun onih koji su u ime katolika željeli razračunati s liberalizmom i modernitetom doživio je neuspjeh. To je očito uzimajući u obzir dosege Drugog vatikanskog sabora. Mardešić objašnjava da bi bilo pogrešno smatrati da je liberalizam pobijedio katolike i tumači da je model protuliberalnog katoličanstva doživio neuspjeh jer se u sebi urušio i razgradio. ${ }^{21}$

\subsection{Mardešić ukazuje na pluralnost unutar HKP-a u odnosu na kulturu}

Mardešić promišlja o unutrašnjim polemikama unutar katoličkih krugova u Hrvatskoj s početka 20. st. u kojima se sve više postavljalo i pitanje odnosa prema modernoj kulturi, posebno književnosti. Ljubomir Maraković, inače vjerni učenik Antuna Mahnića, pratio je inozemnu književnost i film te nerijetko pozitivno prikazivao kulturna postignuća u modernoj Europi, što se, tvrdi Mardešić, nije uvijek slagalo sa strogim mjerilima Mahnićeve katoličke estetike. ${ }^{22}$ Mardešić piše da je pritom najviše bio napadan Silvije Strahimir Kranjčević (1856.-1908.), jedan od najpoznatijih hrvatskih pjesnika. U njemu je Mahnić, tvrdi Mardešić, otkrivao nekršćanski pesimizam i poguban utjecaj njemačkog filozofa Arthura Schopenhauera, niječući pravo pjesnika da bude

\footnotetext{
${ }^{20}$ Mardešić, Hrvatski katolički pokret i liberalizam..., 262.

${ }^{21}$ Isto, 267.

${ }^{22} \mathrm{O}$ odnosu HKP-a prema znanosti i kulturi pisao je i Franjo Velčić obrađujući među ostalim i Ljubomira Marakovića: Franjo VELČIĆ, Odnos Hrvatskog katoličkog pokreta prema znanosti i umjetnosti (Maraković, Grgec, Binički), u: Mardešić, Hrvatski katolički pokret i liberalizam..., 347-357.
} 
tužan i nesmiren u svojoj iskrenosti. ${ }^{23}$ Još u Gorici, podsjeća Mardešić, u listu Rimski katolik, kojega je Mahnić pokrenuo, mnoge su stranice bile posvećene pobijanju prosvjetiteljske ideologije. Smatrajući da je liberalizam prodro $u$ svjetsku književnost, građanski tisak i modernu filozofiju, svi su se onodobni poznatiji književnici u Sloveniji (J. Stritar, F. Prešern, S. Gregorčič) našli na udaru bespoštedne prosudbe i nepovratne Mahnićeve osude za slobodarstvo, tvrdi Mardešić. ${ }^{24}$

Neodvojivo od liberalizma, Mardešić promatra i modernizam, odnosno nova gibanja unutar katoličke teologije na prijelazu 19. u 20. stoljeće. Modernizam Mardešić naziva »teološkim oblikom liberalizma«. ${ }^{25}$ Piše i o polemici koja je izbila unutar Crkve kad je početkom 20. stoljeća val modernizma bio zapljusnuo hrvatski katolički prostor. Radilo se u knjizi O modernoj katoličkoj apologetici, tada mladog i poletnog teologa Frana Barca (1872.-1940.) koji se isticao novim idejama i netradicionalnim prosudbama, djelu u kojem se u $\mathrm{Hr}$ vatskoj straži razbuktala nevjerojatno oštra i burna polemika. ${ }^{26}$ List je optužio knjigu za modernizam, a u obranu Barca ustao je profesor Antun Bauer, kasniji zagrebački nadbiskup. Sve je bilo upereno protiv te knjige koju se sumnjičilo za krivovjerje. Prvi je protiv nje ustao Fran Biničkii ${ }^{27}$ (1875.-1945.), a kasnije se osudama pridružio Antun Alfirević (1875.-1945.), Karlo Eterović (1874.-1935.), a napokon i sâm Anton Mahnić. Mardešić piše da je Fran Barac začudo izašao pobjednikom u tom teološkom prijeporu, ali da se sukob s onim što se optuživalo za modernizam u hrvatskom katolicizmu nastavio i dalje, makar u drugačijim oblicima. ${ }^{28}$

Kampanji Hrvatske straže umnogome je pridonijela tada objavljena enciklika Pija X. Pascendi Dominici gregis, usmjerena protiv novosti u katoličkoj teologiji, prozvanima skupnim imenom modernizam. Mardešić spominje i druge slične primjere, poput odnosa teologije prema evoluciji, nekršćanskim religijama, radničkom pitanju, kozmologiji, povijesti itd. ${ }^{29}$

\footnotetext{
${ }^{23}$ Prije spomenuti rad Franje Velčića prenosi znatno umjerenije sudove o Silviju Strahimiru Kranjčeviću objavljene u Hrvatskoj straži 1903. (usp. F. VELČIĆ, Odnos Hrvatskog katoličkog pokreta prema znanosti i umjetnosti, 350).

${ }^{24}$ Mardešić, Hrvatski katolički pokret i liberalizam..., 260.

${ }^{25}$ Isto, 264.

${ }^{26}$ Mons. dr. Fran Barac (1872.-1940.), hrvatski katolički svećenik, sveučilišni profesor, teolog i političar. Više o njemu vidi Ivica ZVONAR, Dr. Fran Barac (1872.-1940.), Zagreb, Katolički bogoslovni fakultet - Kršćanska sadašnjost, 2016.

${ }^{27}$ Fran Binički (1875.-1945.), hrvatski svećenik, pisac, filozof, novinar i esejist.

${ }^{28}$ Mardešić, Hrvatski katolički pokret i liberalizam..., 264-5; Mardešić, Rascjep u svetom..., 834835. Nedostaje u Hrvatskoj literatura o moderniznu jer to pitanje u hrvatskoj teologiji na početku 20. st. još treba biti temeljito proučeno.

${ }^{29} »$ Nitko nije u onodobnim raspravama slutio da isti prijepor o autonomiji umjetnosti u sebi skriva zapravo mnogo širi problem autonomije zemaljskih vrednosta, što će baš na Drugom vatikanskom koncilu postati glavnom točkom obrata i preokreta u odnosu prema integrističkoj i bojovnoj tradiciji Crkve. Već je dakle onda bila ozbiljno stavljena u pitanje ideološka slika kršćanstva, pa i u prilici kad njezini nositelji nisu toga uvijek i do kraja bili svjesni« (Mardešić, Rascjep u svetom..., 805).
} 
Prenoseći sud Tomislava Janka Šagi-Bunića o biskupu Antonu Mahniću, Željko Mardešić hvali djelovanje krčkog biskupa u korist glagoljice i vrednovanja uloge laika u Crkvi, ali kritički procjenjuje Mahnićev posve negativan odnos spram liberalizma i njegov stav prema društvenom poretku. Danas kršćani mogu zastupati tezu o slobodnoj Crkvi u slobodnoj državi, za koju je Mahnić mislio da se ne može zastupati, tvrdi Šagi Bunić a prenosi Mardešić. Nastavlja tvrdeći da, nakon što je Drugi vatikanski koncil objavio deklaraciju o vjerskoj slobodi Dignitatis humanae, katolici mogu bez straha zastupati tezu o slobodnoj Crkvi u slobodnoj državi, a to je Mahniću bilo neprihvatljivo. ${ }^{30}$ Pohvaljujući »kristovski univerzalizam« Ivana Merza, Mardešić prepoznaje beatifikaciju Ivana Merza kao vrlo pozitivan znak u Crkvi u Hrvatskoj. On smatra dobrim da za uzor laicima u Hrvatskoj Crkva ne stavlja bojovne autore iz Hrvatske stra$\check{z} e$, ali je svoj sud Mardešić izrekao prije negoli je započeo proces Mahnićeve beatifikacije 2013. godine. ${ }^{31}$

\section{Odbacivanje političkog katolicizma, vrednovanje demokracije i sekularizacije}

U pitanju odnosa katolika prema liberalizmu, od velike su važnosti i kategorije političkog katolicizma, demokracije i sekularizacije. Mardešić se vrlo kritički odnosi prema političkom katolicizmu u prošlosti, kao i njegovim pojavljivanjem u suvremenom hrvatskom društvu nakon uvođenja višestranačja. Pritom smatra da su za politički katolicizam najveći neprijatelji bili upravo liberalizam i modernizam, jer su oni Crkvi oduzimali vlast u društvu i svijetu. Na meti njegove kritike je moć Crkve shvaćena na svjetovan način, uplitanje religije u svjetovne sukobe i društvene borbe, što je, po njegovu mišljenju, uzrokovalo sve manji interes za pojedinca. ${ }^{32}$ Za politički katolicizam Mardešić kaže

${ }^{30}$ Usp. Tomislav ŠAGI-BUNIĆ, Mahnićeva poruka današnjim katolicima u Hrvatskoj, Svesci, 1718 (1970) 116-119.

${ }^{31}$ Kao zaključak ovog poglavlja Željko Mardešić prenosi riječi blaženika Ivana Merza koji je 1916. svjedočio za čisti kristovski univerzalizam: »Znao sam već davno da ima razlika i da su se neka politička pitanja uvukla u naš pokret, u kojemu po mom mišljenju, ne bi smjelo biti političkih pitanja. Mislim da se toga treba čuvati nego svih naših vanjskih neprijatelja« (Dragutin KNIEWALD, Sluga Božji Ivan Mertz, Zagreb, Župski ured sv. Petra, 1988, 82). Željko Mardešić ne znajući da će se proces Mahnićeve beatifikacije koju godinu poslije ipak pokrenuti, piše: »Tako se Crkva ne priprema uzdići na oltar svetosti u naše doba ni A. Mahnića niti njegove bojovne učenike iz Hrvatske straže. Čini to za jednog skromnog, dobrog, mladog, pobožnog i obrazovanog vjernika koji je u najtežim vremenima hrvatskog kaosa i ideološkog ludila svjedočio za čisti kristovski univerzalizam i protiv pogubne političnosti katolicizma u Hrvatskoj. Riječ je naravno o blagom i patničkom Ivanu Merzu« (Mardešić, Rascjep u svetom..., 844). Proces za beatifikaciju Antona Mahnića Krčka biskupija pokrenula je 2013. godine.

${ }^{32}$ Mardešić tvrdi da su pitanja politike i vlasti udaljili Crkvu »od siromašnog puka, kojeg su očito mučile druge brige i teže kušnje [...] pa je pojedinac u njoj nužno počeo igrati sve manju i beznačajniju ulogu, čime je bila neizravno zaustavljena predmoderna individualizacija, sretno 
da ide za uspostavljanjem predgrađanske prisutnosti i utjecaja Crkve u društvu, za feudalnom Crkvom koju označava bojovnost, isključivost i nadzor. Tvrdi da politički katolicizam gaji nostalgiju za teokratskim ustrojem društva te da takav predgrađanski duh izbija u raznim strujama političkog katolicizma dok se one susreću s više povijesnih strujanja - reformacijom, prosvjetiteljstvom, liberalizmom, socijalizmom i komunizmom..$^{33}$ Umjesto političkog katolicizma, Željko Mardešić u političkoj sferi upire pogled prema personalizmu Emmanuela Mouniera. ${ }^{34}$

Mardešić snažno vrednuje demokraciju pozivajući se na povijesni proces $u$ kojem je Crkva postupno došla do vrednovanja demokracije, nakon odbijanja liberalnog poretka u 19. stoljeću i tragičnog iskustva autoritarnih sustava totalitarizma 20. stoljeća. ${ }^{35}$ Tvrdi da se još »jučer možda moglo biti kršćaninom bez pristanka uz demokraciju, danas više ne; tko to ne razumije, izgubljen je $u$ vremenu i čini veliku štetu svojoj vjeri i bližnjemu«. ${ }^{36}$

Željko Mardešić rijedak je primjer među hrvatskim katolicima vrlo pozitivnog vrednovanja sekularizacije. ${ }^{37}$ Za njega je sekularizacija proces postajanja svijeta svjetovnim i priznavanja »autonomije zemaljskih stvari« o kojoj govori Drugi vatikanski sabor u Pastoralnoj konstituciji Gaudium et spes (br. 36). ${ }^{38}$ Ukazujući da upravo kršćanstvo omogućuje sekularizaciju, Mardešić razlikuje poželjnu sekularizaciju od neprihvatljivog sekularizma. Za njega, dakle, sekularizacija nije nešto protivno kršćanstvu, nego je, ispravno shvaćena, upravo zahtjev biblijske vjere u Boga Stvoritelja koji priznaje autonomiju svijeta koji je stvorio. Po Mardešiću, sekularizacija ne uništava kršćanstvo, nego bi se prije moglo reći da ga čisti od nekršćanskih sadržaja i od nekršćana koji su

proistekla iz grčke filozofije, rimskog prava i kršćanske evanđeoske zajednice« (Mardešić, Rascjep u svetom..., 661).

${ }^{33}$ Mardešić, Rascjep u svetom..., 106, 215.

${ }^{34}$ Osnivač francuskoga personalističkog pokreta u tridesetim godinama 20. stoljeća bio je Emmanuel Mounier. On je 1932. pokrenuo časopis Esprit, a sljedećih je godina definirao filozofski, ideološki i politički osobit personalistički pokret. Središnja ideja Mounierove personalističke filozofije bila je aktivni angažman za novu civilizaciju, kojoj je u centru dostojanstvo ljudske osobe, a protivi se jednako individualizmu kao i kolektivizmu.

$35 \gg$ Kroz zadnja stoljeća mnogi su katolici odlučno odbacivali i neprizivno osuđivali svaku demokraciju smatrajući je središnjim krivovjerjem modernoga doba. Tek će na Božić 1944. godine Pio XII. priznati vrednote demokracije jer su upravo u završenom II. svjetskom ratu nedemokratski sustavi doživjeli neiskupljiv i potpun poraz: ne samo vojni nego i moralni. [...] Od tada katolici mijenjaju stajalište i postaju najgorljivijim braniteljima i zagovornicima demokracije« (Mardešić, Odgovornost kršćana za svijet, 23).

${ }^{36}$ Isto, 25.

${ }^{37}$ O sekularizaciji Mardešić je pisao više puta: Rascjep u svetomu, 243-310, 693-729; Kršćanstvo i sekularizacija, Nova prisutnost, 4 (2006) 2, 256-280 članak prije toga objavljen u Diacovensiji. Pavle Kufrin posebno je obradio Mardešićev odnos spram sekularizacije u članku: Kršćanstvo i sekularizacija u viziji Željka Mardešića, Nova prisutnost, 9 (2011) 2, 487-492.

38 »Ako pod autonomijom ovozemnih stvarnosti podrazumijevamo da stvorene stvari pa i sama društva imaju vlastite zakone i vrijednosti koje čovjek mora pomalo otkrivati, primjenjivati i sređivati, onda je sasvim opravdano zahtijevati takvu autonomiju: to je ne samo zahtjev ljudi našega vremena, nego odgovara i volji Stvoritelja« (GS 36). 
samo hinili kršćanstvo. Mardešić čak priznaje sekularizaciji pomoć vjerniku u njegovu kvalitativnom rastu, jer je sekularizacija ne hoteći pomogla vjeri da postane duhovnijim i slobodnijim činom osobnog uvjerenja pojedinca. Zbog nje kršćani danas više ne mogu biti vjernici po običaju ili iz koristi, jer ih okoliš neprestance propitkuje. ${ }^{39}$ Sekularizacija je za Mardešića vrlo korisna za vjeru i kršćane jer pomaže Crkvi da bude autonomna i slabi joj političnost, ali u isti mah otvara slobodan prostor za jačanje religioznosti religije. Gubitak političke moći pomaže Crkvi da ona postane ujecajnija u društvu, ali sada zbog vjerskih, a ne više svjetovnih razloga. Mardešić smatra da putem sekularizacije Crkva ima prigoduu biti vjernija sebi i bliža svojim evanđeoskim izvorima. ${ }^{40}$

\section{Koncil - put dijaloga Crkve i moderniteta}

Kao što je bio ključan za oblikovanje Mardešića kao katoličkog vjernika i intelektualca, Drugi vatikanski koncil je od središnje važnosti i za njegov stav prema liberalizmu. Za Mardešića je Koncil značio povratak biblijskom kršćanstvu ili, bolje rečeno, povratak Svetom pismu koje prethodne generacije nisu dovoljno poznavale, a putem Biblije i susret s teologijom. On ponizno svjedoči da se smatra obraćenikom na biblijsko kršćanstvo, nakon što je prethodno pripadao masi pretkoncilskih katolika radi obiteljskih običaja i nacionalne tradicije. Za njega je Koncil bio »otkriće kršćanstva, a otkriće kršćanstva potvrdu Drugog vatikanskog koncila. ${ }^{41}$

Za Mardešića Drugi vatikanski koncil znači preokret u odnosu Crkve, liberalizma i modernog razdoblja. On tvrdi da je došlo do promjene polazeći od odnosa Crkve i modernog svijeta, a ne Crkve i liberalizma, jer se u koncilskim dokumentima uopće ne spominje pojam liberalizam. Koncilski oci izostavljaju liberalizam, ali učestalo spominju moderni svijet jer je tu i nastala najveća novost. Nema više osude modernog svijeta kao u 19. stoljeću, napušta se pokušaj obnove predliberalnog društva, koji je zaokupljao mnoge katolike u 19. i početkom 20. stoljeća. Sada se Crkva stavlja u dijalošku poziciju spram svijeta, ali i više od toga - Crkva počinje i učiti od svijeta, a ne samo svijet od Crkve, kao do tada. U liberalnom modernom svijetu postoje i Crkvi i kršćanstvu prihvatljive vrjednote. Iz toga dalje proizlazi da se Crkva zapravo počela prilagođavati poretku slobode kasnije nego što se susljedno prilagođavala teokratskim državama, feudalnom bespravlju i zahtjevima monarhijskih vlastodržaca, koji svi

\footnotetext{
${ }^{39}$ Mardešić, Kršćanstvo i sekularizacija..., 270-273, 279.

${ }^{40}$ Ivan ŠARČEVIĆ, Lukavstvo svetog? Mardešićevo razumijevanje političkog katolicizma, Nova prisutnost, 9 (2011) 2, 450; usp. MARDEŠIĆ, Rascjep u svetom..., 269 i 431.

${ }_{41} \gg$ Velik dio mojeg naraštaja tek preko Drugog vatikanskog koncila došao [je] do Biblije, a onda i teologije. Do tada smo se uzaludno koprcali u besplodnoj filozofskoj polemici, naivno misleći da neprijatelje možemo uvjeriti da su u krivu, a mi ostati samodostatno u pravu « [Željko MARDEŠIĆ, Koncilski paradoksi - velike nade i mali ishodi, Nova prisutnost, 9 (2011) 1, 14].
} 
zajedno, tvrdi Mardešić, sigurno nisu bili veći kršćani od današnjih demokrata, ukoliko se kršćanstvo mjeri po dobrim djelima, a ne po razmetljivoj samohvali pripadanja Crkvi. Svjedočenje u svijetu i služenje svijetu preuzimaju mjesto pretkoncilskim osudama svijeta. To je posve nov način razmišljanja u kojemu Mardešić posebice ističe koncilsku Deklaraciju o vjerskoj slobodi Dignitatis humanae. ${ }^{42}$

\section{Modernitet ne bi bio moguć bez kršćanstva}

Mardešić ističe ono što su teolozi pretkoncilske Crkve redovno previđali, tj. činjenicu da je samo kršćanstvo u svojem izvornom obliku bilo i ostalo nezaobilaznim čimbenikom rađanja moderniteta. Drugim riječima, bez takva kršćanstva ne bi liberalizam ni modernitet uopće mogli nastati. Zato, tvrdi Mardešić, današnje kršćanstvo uspijeva gotovo u potpunosti prisvojiti sastojke moderniteta: obranu ljudskih prava, demokraciju, napredak, pravnu državu, društvenu pravdu, snošljivost i mirotvorstvo. Iako su te odrednice nastale u otvorenoj oporbi prema vjeri, Crkva ih u naše doba ne samo prihvaća nego ih smatra svojim vrednotama, što potkrepljuje Mardešićevu tvrdnju o kršćanskim izvorima moderniteta. On ukazuje na to da modernitet i liberalizam imaju zapravo svoj korijen u kršćanskom poimanju ljudske osobe i njezine neotuđive slobode, pa i pred svemoćnim Bogom. Mardešić povlači neprekinutu crtu između prvog kršćanstva i kasnijeg moderniteta, koju je službena Crkva dugo godina uporno odbacivala priznati. Mardešić poručuje katolicima da kao vjernici ne budu povrijeđeni u taštini što ih je modernitet preduhitrio učinivši ono što je bila njihova dužnost - uvrstiti slobodu u čin povjerenja u Boga. ${ }^{43}$

\section{Umjesto zaključka - dijalog kršćanstva i liberalizma je moguć}

Za Željka Mardešića Drugi vatikanski koncil znači obrat i svršetak razdoblja osude liberalizma. Došlo je do promjene polazeći od odnosa Crkve i modernog svijeta, a ne Crkve i liberalizma jer se, primjećuje Mardešić, u cijelom koncilskom tekstu niti jednom ne spominje riječ liberalizam. Upravo zato koncilski tekstovi imaju mnogo toga o modernom svijetu, jer je tu i nastala najveća novost. Po Mardešiću, ta je novost u tome da je izostalo ne samo izopćenje modernog svijeta, nego je s njim poveden iskren razgovor, dok je Crkva istodobno napustila stoljetni pokušaj obnove predliberalnog društva. Mardešić podsjeća da Crkva želi biti Mater et Magistra; ne samo učiteljicom, već i majkom, pa joj više ne pristaje izricati svečane osude zabludâ modernog svijeta. To je onda razlogom da se

\footnotetext{
${ }^{42}$ Jukić, Kršćanstvo i liberalizam, 897.

${ }^{43}$ Isto, 836-837; Mardešić, Rascjep u svetom..., 836-837.
} 
uloga kršćanina iskazuje sve manje kao obrana i bojovno proširenje nazočnosti Crkve, kako je često prije bio slučaj. U tom sklopu, ističe Mardešić, posebice je važna koncilska misao da i Crkva mora početi učiti od svijeta, a ne samo svijet od Crkve, kao dosad, što upućuje na to da bi među prihvatljivim vrijednostima mogli biti i slobodarski prinosi liberalizma modernom svijetu, jer je taj svijet zapravo isto što i njegova liberalna srž. Iz toga proizlazi, zaključuje Mardešić, da se Crkva zapravo samo počela prilagođavati poretku slobode, bez obzira na njegove djelomične zle posljedice, kasnije nego što se susljedno prilagođavala teokratskim državama, feudalnom bespravlju i zahtjevima monarhističkih vlastodržaca, koji svi zajedno sigurno nisu bili veći kršćani od današnjih demokrata, ukoliko se kršćanstvo mjeri po dobrim djelima, a ne po razmetljivoj samohvali pripadanja Crkvi. Zato umjesto nekadašnje borbe protiv svijeta, u drugoj polovici 20. st. i nakon Koncila, u prvi plan dolazi svjedočenje u svijetu, što je moralna kategorija par excellence. Za ostvarenje tog novog načina razmišljanja najvažnija je koncilska Deklaracija o vjerskoj slobodi, Dignitatis humanae. Njome se, tvrdi Mardešić, zaokružuje pomirenje Crkve i liberalizma. ${ }^{44}$

Gledano s druge strane, ni liberalizam nije ostao jednak onome iz prvog razdoblja. U njemu slabe ideološki naboji i stišavaju se bojovne strasti. No liberalizam je takav postao tek poslije dužeg sukoba s dvama pokretima koji su ga tijekom 19. i 20. stoljeća pokušavali srušiti: romantičnim nacionalizmom i radikalnim socijalizmom. Poistovjećen s modernim svijetom, on u trenutku svoje pobjede nad suparnicima otkriva da je, slično katolicizmu, izgubio ideološki poticaj i počeo se desakralizirati. Nestalo je s vremenom u njemu nesnošljivosti prema Crkvi i povijesnom kršćanstvu.

Dijalog između liberalizma i kršćanstva, moguć je i poželjan. Ukoliko je u 19. st. prevladavala suprotstavljenost između dvaju pogleda na društveni poredak, ali i šire između dvaju pogleda na svijet, znanstvenog i vjerskog, koji su se međusobno isključivali, danas - zajedno sa Željkom Mardešićem - možemo utvrditi da je taj dijalog ostvariv i da je potreban. O tome svjedoče liberali koji jesu kršćani, ali i kršćani koji su prihvatili liberalno ustrojstvo društva. Spomenimo da je jedan od najpoznatijih liberalnih mislilaca, John Rawls, bio kršćanin. ${ }^{45}$ Od hrvatskih katolika Mardešić je bio jedan od naglasnijih zagovaratelja susreta kršćanstva i modernog svijeta na principima koncilskog nauka.

\footnotetext{
${ }^{44}$ Jukić, Kršćanstvo i liberalizam..., 896-897. Glede Dignitatis humanae vidi: Marko MEDVED, Katolici i politika: od Syllabusa Pija IX. do Drugog vatikanskog koncila, Riječki teološki časopis, 21 (2013) 2, 341-362; Mile BABIC, Kršćanstvo od državne religije do slobode vjerovanja, Concilium, 52 (2016) 4, 17-29.

${ }^{45}$ Među suvremenim hrvatskim filozofima također postoji svijest o potrebi i važnosti dijaloga kršćanstva i liberalizma. Riječki filozof Elvio Baccarini piše: »Postoje dakle i relevantne mogućnosti za zajednički razgovor i međusobno uvažavanje liberalizma i kršćanstva (o čemu, uostalom, svjedoči i činjenica da postoje liberali koji jesu kršćani, a među njima je najpoznatiji liberalni autor dvadesetoga stoljeća John Rawls), što je, štoviše, i poželjno, s obzirom da je riječ o dvjema najutjecajnim tradicijama u zapadnjačkoj civilizaciji. Temelj takvog razgovora, naravno, treba biti poštovanje dostojanstva i prava čovjeka, upravo kakvo se nalazi, na pri-
} 


\section{Marko Medved" - Nataša Varga Padovan**: \\ Liberalism and the Catholic Church - Željko Mardešić's dialogic vision}

\section{Summary}

Among the Catholics in Croatia, Željko Mardešić was one of the most outspoken advocates of the convergence of Christianity and liberalism, that is, of dialogue between people of faith and the modern world based on the principles of the conciliar teachings. Competently familiar with religious trends in both Croatia and the rest of the world, he was never a mere academic intellectual, but an authentic Christian. His scholarly and religious engagement was strongly influenced by the Second Vatican Council. Whereas the $19^{\text {th }}$ century was dominated by opposition between the two world views, the scientific and the religious one, as well as treatment of social order, Željko Mardešić argued that a dialogue between Christianity and modernity was now necessary and feasible on the basis of the Second Vatican Council. Pointing to the Christian principles of modernity, rejecting political Catholicism and validating democracy and secularisation, Mardešić drew an unbroken line between the first Christianity and modernity.

Key words: Željko Mardešić, liberalism, Catholicism, integrism, Second Vatican Council, secularisation.

(na engl. prev. Darko Poslek)

mjer, u Povelji [o ljudskim pravima UN-a], koju ispravno Devčić prikazuje kao vrijedan primjer pristupa ljudskom dignitetu« (Elvio BACCARINI, Etika u suvremenom svijetu. Ivan Devčić o moralnim pitanjima suvremenog svijeta, u: Aleksandra GOLUBOVIĆ - Iris TIĆAC (ur.), Vječno u vremenu, Zbornik u čast prof. dr. sc. Ivana Devčića u povodu 60. obljetnice života, 30. obljetnice profesorskog rada i 10. biskupstva, Zagreb - Rijeka, Kršćanska sadašnjost - Teologija u Rijeci, 2010, 294).

* Marko Medved, PhD, Assis. Prof., Department of Church History, Faculty of Catholic Theology (Study of Rijeka), University of Zagreb; Address: Omladinska 14, HR-51000 Rijeka, Croatia; E-mail: markofelix@yahoo.com.

***Nataša Varga Padovan, MA; Address: Mihačeva Draga 21, HR-51000 Rijeka, Croatia; E-mail: natashavarga@yahoo.com. 